\author{
"Mircea cel Batran" Naval Academy Scientific Bulletin, Volume XX - 2017 - Issue 1 \\ The journal is indexed in: PROQUEST / DOAJ / Crossref / EBSCOhost / INDEX COPERNICUS / DRJI / OAJI I \\ JOURNAL INDEX I I2OR / SCIENCE LIBRARY INDEX / Google Scholar / Academic Keys/ ROAD Open Access I \\ Academic Resources / Scientific Indexing Services / SCIPIO / JIFACTOR
}

\title{
NEOCLASSICAL WORD FORMATION IN THE ROMANIAN MARITIME VOCABULARY
}

\author{
Corina SANDIUC ${ }^{1}$ \\ ${ }^{1}$ Assistant Mircea cel Batran Naval Academy, ema_sandiuc81@yahoo.co.uk
}

\begin{abstract}
The process of neoclassical word formation is extremely productive in the formation of the international scientific and technical terminology. Currently, we can detect a wide variety of neoclassical word formation elements, also called suffixoides and prefixoides, in the structure of the Romanian maritime terms. Prefixoids and suffixoids differ from the ordinary prefixes and suffixes in the fact that they have a high degree of lexical and semantic autonomy, given by the fact that they originate from themes, which in the language of origin (Hellenic or Latin), had a meaning of their own, being nominal, pronominal or verbal themes. Prefixoids and suffixoids enrich the meaning of the concept, to which they emphasize the degree of accuracy. Some of these elements have known an increasing productivity as we approach the current period. This is eloquently proven by the fact that we find them attached to inherited root words (e.g. supravieţuire, suprafaţă, supraveghea) or to words borrowed from the neighbouring languages, many of them attached to a base of French origin (e.g. suprastructură, supraimersiune). Thus, the predilection for this word formation process is obvious in the Romanian maritime terminology, however the significant number of the terms formed this way does not come as a surprise if we consider the fact that that we are dealing with a booming international language.
\end{abstract}

Key words: word formation, suffixoides, prefixoides, maritime term

As far as the role of prefixoids in the formation of Romanian maritime terms is concerned, some specialists choose to place them inside the word compounding process because of their degree of semantic autonomy. There are also researchers who consider them lexical composition elements+ or Greek-Latin hybrid compounds ${ }^{1}$ while others confer them the status of compound words ${ }^{2}$. At the same time, the precise meaning of these elements has caused some of them to get lexicalized and carve their way into common language, where they are perceived and used as simple words - adjectives or nouns. Thus, came into circulation auto, moto, foto, radio, etc. ${ }^{3}$

The process of pseudoprefixation, enjoys great productivity in the maritime vocabulary as well, where numerous terms of more recent date appeared through composition from an existing term preceded by a prefixoid. Pseudoprefixes, such as aero-, auto-, electro-, hidro-, tele-, radiohave come into being during the last stage of development of the Romanian maritime vocabulary and were used primarily with words with a high degree of specialization.

Clearly, not all maritime terms formed with pseudoprefixes are creations of the Romanian language (e.g. hidrolocaţie), some being calques after foreign terms such as Rom. interpunte, cf. Fr. entrepont "twin-deck", or even loans: transportor, cf. Fr. transporteur "carrier". The distinction between the maritime terms created in Romanian and the neologisms borrowed from French is sometimes difficult to make. However,

\footnotetext{
${ }^{1}$ F. Ciobanu, F. Hasan, 1970, pp. 243-260.

${ }^{2}$ Vezi Al. Graur, 1965, p. 65.

${ }^{3}$ See also P. Léon şi P. Bhatt, 2005, p. 155.
}

after analyzing the corpus, we can say that most of the terms discussed have appeared in Romanian via French, the more so as prefixoids are preferably attached to neologisms. We list here a number of frequently used prefixoids, noting that most of them come from Greek or Latin, through direct loans or via French.

\section{Locative prefixoids}

This type of prefixoids specify the spatial orientation of an object, phenomenon, or action, or the environment in which an object is used, given by the base of the derived word:

$$
\begin{aligned}
& \text { a. inter- (< Lat. inter, Fr. inter- "between") } \\
& \text { e.g.: intercostal, intercontinental, } \\
& \text { internaţional, interpunte, etc. }
\end{aligned}
$$

These word-formations are mainly adjectives, and less frequently, adverbs.

b. sub- (< Lat. sub; Fr. sub-) is a

composition element that indicates a quality or the lower position of an element relative to another. Such terms were born on Romanian territory (subbraţare, subcentură, subtraversare, subunitate, subfluvial, etc.) or imitate French patterns:

Rom. submarin, cf. Fr. sous-marin "submarine";

Rom. subofiţer, cf. Fr. sous-officier "petty officer";

Rom. subacvatic, cf. Fr. subaquatique "underwater";

\footnotetext{
${ }^{4}$ We mention here the etymological twins inter- and intre- which gave birth to calques after Western models (e.g. întreprinde, cf. Fr. entreprendre).
} 


\section{"Mircea cel Batran" Naval Academy Scientific Bulletin, Volume XX - 2017 - Issue 1 \\ The journal is indexed in: PROQUEST / DOAJ / Crossref / EBSCOhost / INDEX COPERNICUS / DRJI / OAJI I JOURNAL INDEX I I2OR / SCIENCE LIBRARY INDEX / Google Scholar / Academic Keys/ ROAD Open Access I \\ Academic Resources / Scientific Indexing Services / SCIPIO / JIFACTOR}

Rom. subarbă, cf. Fr. sous-barbe "gob line", etc.

c. supra- (< Lat. supra, Fr. supra- "above", "over") is a prefixoid of Latin origin, which appears in the Romanian maritime vocabulary via French, appearing in many calques, where, most often, it is equivalent to the French prefix sur-, and in fewer cases to the French prefix super: ${ }^{5}$

Rom. supraveghea, cf. Fr. surveiller "to survey";

Rom. supravieţui, cf. Fr. survivre "to survive";

Rom. suprafaţă, cf. Fr. surface "surface"; Rom. suprastructură cf. Fr. superstructure,"superstructure" etc.

d. trans- (< Fr. trans-, cf. Lat. trans "over") This prefixoid appears in Romanian at the end of the eighteenth century through the Romance languages and appears quite frequently in the scientific style. It is part of many international, technical terms, such as: transatlantic, transoceanic, transcontinental, transborda, transfilaj, transmisie, transportabil, transportor, etc.

e. tele- (< Fr. télé-, cf. Gr. tele „far”, „from afar") appears in terms, such as: telefon, telegraf, telemetru, telecomunicaţii, telescop, televiziune, etc.

These constructions, as well as those with -trans, are mostly direct loans from French. Among the prefixoids indicating the environment, the most frequent is, for obvious reasons, hidro-. This appears in borrowed structures, such as: airplane";

Rom. hidroavion < Fr. hydroavion "hydro-

Rom. hidrofon < Fr. hydrophone "hydrophone";

Rom. hidroglisor < Fr. hydroglisseur "glider";

Rom. hidrograf < Fr. hydrographe, "hydrograph";

Rom. hidrografie < Fr. hydrographie "hydrography".

Or in structures created in Romanian, such as:

hidrograd < hidro- + grad

hidrolocaţie < hidro- + locaţie "hydrolocation".

\footnotetext{
${ }^{5}$ Super- was also borrowed via French (< Fr. super-, Lat. super- „over”, „above”, „very”) as mark of maximum intensity. When compared to supra-, super-
is quite unproductive in the Romanian maritime maximum intensity. When compared to supra-, super-
is quite unproductive in the Romanian maritime vocabulary (e.g. supernavă).
} DOI: 10.21279/1454-864X-17-I1-085
The prefixoid hidro- is followed by the other neological environment indicating prefixoids (aero-, termo-, foto-, geo-), which are less productive:

aeronaval, aeromaritim, termoclină, termohalin, fotoelectric, geocentric, geomagnetic, geodezic, etc.

f. Radio- (< Lat. radius, Fr. radio-) refers to electromagnetic radiation in relation to an object or an instrument, and is a highly productive compounding element in the Romanian maritime language. It is used in the formation of nouns, adjectives and verbs, as follows:

radiobaliza, radiobaliză, radiofar, radioreceptor, radioreceptie, radiosextant, radionavigaţie, radiolocaţie, etc.

Except for the term radiosextant, which is formed in Romanian, most terms formed with this pseudoprefix represent loans taken as such from French (except radiolocaţie, which appears to have uncertain origin, either English, French or Russian).

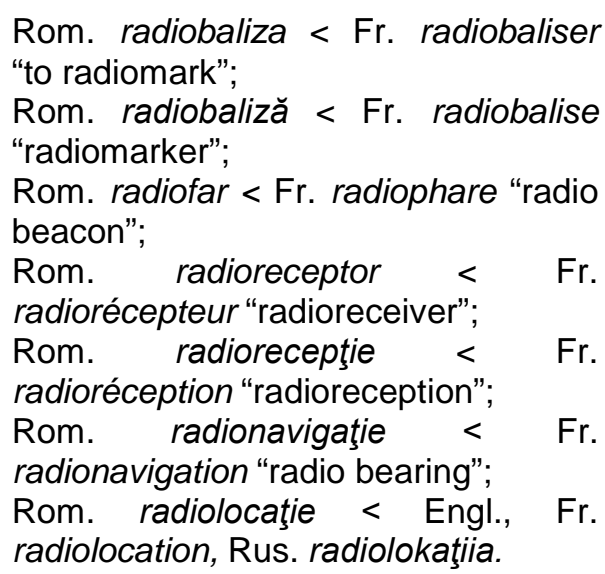

\section{Atitude prefixoids}

a. The prefixoid anti - meaning "against", "opposite" appeared in Romanian language together with the Romance derived words and became productive in the maritime language where it derives nouns and adjectives. The terms created on Romanian territory (antidesant, antilunar) can be easily confused with the loans (antifon, anticiclon, antiaerian, antimagnetic, antisolar, etc.) or the calques (Rom. antisubmarin, cf. Fr. antisous-marin).

b. The prefixoidul contra- (< Fr. contre-, Lat., contra- „against”, „opposed”) is attached especially to nouns and verbs. In this case, the distinction between Romanian creations and loans can be a difficult task 


\section{"Mircea cel Batran" Naval Academy Scientific Bulletin, Volume XX - 2017 - Issue 1 The journal is indexed in: PROQUEST / DOAJ / Crossref / EBSCOhost / INDEX COPERNICUS / DRJI / OAJI I JOURNAL INDEX I I2OR / SCIENCE LIBRARY INDEX / Google Scholar / Academic Keys/ ROAD Open Access I Academic Resources / Scientific Indexing Services / SCIPIO / JIFACTOR}

for researchers, especially since some of the terms do not appear in the Romanian dictionaries (e.g. contrabord, contrabraţ, contracarenă, contrachilă, contraelice, contra-inundare, contrazburător, etc.). Except for a few terms created in Romanian (e.g. contrazburător, contrainundare), most terms formed with this prefixoid are calques or loans from French:

Rom. contraamiral < Fr. contre-amiral "rear admiral";

Rom. contraatac < Fr. contre-attaque "counterattack";

Rom. contrabord < Fr. contre-bord "opposite course";

Rom. contra-bulină < Fr. contrebouline "type of manoeuvre";

Rom. contracarenă < Fr. contrecarène "side hull";

Rom. contracarlingă < Fr. contrecarlingue "side keelson";

Rom. contrachilă < Fr. contre-quille "rising wood";

Rom. contracivadieră < Fr. contrecivadière "square sail placed under the bowsprit";

Rom. contracurenţi < Fr. contrecourant "countercurrent";

Rom. contraelice < Fr. contre-helice "counter propeller";

Rom. contraetravă < Fr. contre-étrave "counter stem";

Rom. contrafoc, cf. Fr. contre-feu "jibber-jib";

Rom. contragabier < Fr. contregabier "upper topsail";

Rom. contramarş < Fr. contremarche "two (groups of) ships moving on parallel and opposite tracks";

Rom. contramina < Fr. contre-miner "counter-mine";

Rom. contratorpilor < Fr. contretorpilleur "torpedo destroyer", etc.

From a semantic point of view, contracan stand for: ${ }^{6}$

- the vicinity: contrafort, contrabord, contracarlingă, contrachilă, etc.

- the oposition: contrafoc, contra-inundare, contratorpilor, contramina, etc.

- the equivalence: contrabalansa, contrabraţa, etc.

- the replacement: contraamiral.

c. Auto- (< Fr. auto-, gr. autos) is a compounding element meaning "self, by

${ }^{6}$ Cf. I. Iordan, 1956, p. 303. oneself", found mainly in terms formed in Romanian: autoamfibiu, autodirijare, autoinstalaţie, autostaţie, etc. Unlike other formative elements, loans in this case are rare (e.g. autoportant).

d. (< Fr. porte-) has the lexical-semantic significance of "carrier" and can be found in Romanian lexical constructions, such as: portrachete, portbarje, portmine, etc., or in terms of French origin: portavion, portelicopter, portcontainer, etc.

\section{Prefixoids of degree, dimension and number}

This category of affixes are predominantly recent loans from modern languages, from the literate Latin or from Greek and indicate, from a semantic point of view, the degree or the dimension of the property, action or object named by the word from which the basis of derivation comes from.

a. izo-, iso- (< Fr. iso-, cf. Gr. isos

„equality”) are elements of linguistic composition that express the idea of equality. The structures built in this way are usually nouns and adjectives formed in Romanian language or borrowed from French.

Rom. izotermobată < izoterm + -bată "line on a map joining points with the same temperature in seawater";

Rom. izocotidală < izo- + cotidală "line joining points with the same tide height";

Rom. izofon < izo- + -fon "line joining points with the same speed of sound in seawater";

Rom. izobar < Fr. isobare "which occurs at a constant pressure";

Rom. izobată < Fr. isobathe; "line joining points with the same depth"

Rom. izoclină < Fr. isoclines "line drawn on a map joining points that have the same declination";

Rom. izotahă / isotahă < germ. Isotache, $\mathrm{Fr}$. isotache "line joining points of a river where the water is of the same speed";

Rom. izogon < Fr. isogone "geometrical figure with two equal angles";

Rom. izohalin < Fr. isohaline "line joining points with the same salinity";

Rom. izoterm < Fr. isotherme; "line joining points on a map with the same average temperature"

Frequently, when forming such terms, a second element of composition is used, such as: -fon (Fr. -phone, cf. gr. phone "sound, voice"), -bar (< Fr. bare "heavy", "load", "pression"), -bată (< Fr. bathe "deep", "refering to deep sea"), -gon (Fr. gone, cf. Gr. gonia "angle"), -term (< Fr. -therme, It. -termo, cf. Gr. thermon "thermal”, „heat") 


\section{"Mircea cel Batran" Naval Academy Scientific Bulletin, Volume XX - 2017 - Issue 1 \\ The journal is indexed in: PROQUEST / DOAJ / Crossref / EBSCOhost / INDEX COPERNICUS / DRJI / OAJI I JOURNAL INDEX I I2OR / SCIENCE LIBRARY INDEX / Google Scholar / Academic Keys/ ROAD Open Access I \\ Academic Resources / Scientific Indexing Services / SCIPIO / JIFACTOR}

b. Semi- (Fr., Lat. semi- „half”) appears in terms formed in Romanian:

e.g. semidunetă "quarterdeck", semipunte "half deck", semiglisor "type of seaplane", semi-port-containăr "type of container ship", etc.

And in some calques:

Rom. semilună, cf. Fr. demi-lune "crescent"

The maritime terms formed with this prefixoid can sometimes give rise to controversy about their etymology, as is the case with semitraversă which is explained differently in different Romanian dictionaries:

Rom. semitraversă, cf. Fr. demi-barrot (DN) "part of a beam"

Rom. semitraversă < semi- + traversă (MDN)

c. The number prefixoids (poly-/multi-, bi-, tri-, cvadri-, mono-) are not very frequent in the Romanian maritime vocabulary. They specify the means of existence of the objects or the characteristics named by the base terms. All affixes in this category are borrowed in the modern era of evolution of the Romanian language and have an international origin and use. ${ }^{7}$ In the corpus we analyzed, we encountered the following terms formed with such prefixes: bimotor "twin engine", binoclu "binoculars", biremă "bireme", ancient oared warship, cvadriremă "cvadrireme, ancient oared warship", polygon " polygon", monogiroscopic, multifuncţional "multifunctional", triunghi "triangle", triunghiular "triangular", tribord "starboard", trigiroscopic, trieră "trireme", triremă "trireme", ancient oared warship", etc.

The examples cited above, indicate the fact that the prefixoids of Greek origin are predominant both quantitatively and in terms of productivity. The frequency of certain terms formed with prefixoids, and the fact that sometimes the prefixoid is added not only to a term, but to more words of the same word family also demonstrates the force of expansion of pseudoprefixes in the Romanian maritime vocabulary. For instance, the productivity of -radio is also highlighted by that fact that we can find it in lexical families borrowed, mostly from French.

E.g.

Rom. radiogoniometrie < Fr. radiogoniométrie "method of determining the direction from which radio waves are emitted;

Rom. radiogoniometru < Fr. radiogoniomètre;

\footnotetext{
${ }^{7}$ See also P. Zugun, 2000, p. 122.
}

Rom. radiogoniometric < Fr. radiogoniométrique;

Rom. radiogoniometra, derivat regresiv din radiogoniometru;

Rom. radiogoniometrare < radiogoniometra + suff. -re.

Also, after analyzing the present corpus, we noticed that, at least in the last phase of development, more terms were formed with prefixoids than with prefixes so that the maritime vocabulary resembles other scientific and technical areas where the massive use of prefixoids is also present. Moreover, many maritime terms so constituted are formed in the same, or almost in the same way in other languages, without clear evidence of which language created them first. However, the current trend in maritime language, like in any other specialized language, is that of internationalization through lexical creation and loans from Romance and Latinate sources, and more recently, massively from English. ${ }^{8}$

\section{The role of suffixoids in the formation} of maritime terms

Another aspect worthy of attention for our analysis is undoubtedly the status of suffixoids in the construction of the Romanian maritime terminology. In this case, as in the case of prefixoids, the affix is a formative element, originally a word by itself, which is actually just a conventional sign equivalent of a noun coming from Greek or Latin, which has a precise meaning and functions as an abbreviated lexical morpheme. $^{9}$

Like the prefixoids, the suffixoids have an international feature, given by the fact that they occur mainly in terms arising from technology and science. In addition to this common feature, the close connection between prefixoids and sufixoids is attested by the fact that a sufixoid can become a prefixoid by simply repositioning it. ${ }^{10}$ In this situation, the structure changes its grammatical category together with the form (e.g. fono- > -fon, termo- > -termic ). ${ }^{11}$

The mobility of these formative elements, which are based on independent and autosemantic words justifies the view that pseudoprefixation would be a variation of word composition. ${ }^{12}$

\footnotetext{
${ }^{8}$ Fl. Dimitrescu, 1994, p.195.

${ }^{9}$ I. Busuioc, M. Cucu, 2003.

${ }^{10}$ Fl. Dimitrescu, op.cit., p. 170.

${ }^{11}$ Cf. I. Iordan, 1948, p. 190 and I. Iordan, 1956, p. 261.

12 See also Florica Dimitrescu Aspects de la pseudopréfixation dans le roumain littéraire actuel (Fl. Dimitrescu, 1970, pp. 925-929) .
} 


\section{"Mircea cel Batran" Naval Academy Scientific Bulletin, Volume XX - 2017 - Issue 1 \\ The journal is indexed in: PROQUEST / DOAJ / Crossref / EBSCOhost / INDEX COPERNICUS / DRJI / OAJI I JOURNAL INDEX I I2OR / SCIENCE LIBRARY INDEX / Google Scholar / Academic Keys/ ROAD Open Access I Academic Resources / Scientific Indexing Services / SCIPIO / JIFACTOR}

In the Romanian maritime terminology, the most common suffixoids are:

a. $\quad$-graf (< Fr. -graphe, It. -grafo, cf. Gr. graphos) is a second element of composition, meaning "that writes", "that draws", "that registers". (In DN)

Among the maritime terms which have in their composition this derivative element, we mention:

anemograf < Fr. anémographe, "anemograph, anemometer that makes a graphical recording";

barograf < Fr. barographe (cf. gr. baros „weight”, graphein „to write”),

"barograph, barometer that records the barometric pressure";

astrograf < Fr. astrographe, "astrograph, telescope used in astrophotography";

cronograf < Fr. chronographe, "chronograph"; declinograf < Fr. déclinographe, "instrument that records the variation of magnetic declination";

maregraf < Fr. marégraphe; "instrument that determines and records water level variation"; oceanograf < Fr. océanographe, "specialist in oceanography";

palograf < Fr. palographe, "instrument for recording the vertical oscillations of a ship";

Some of these nouns are paired with the nouns ended in -grafie, naming sciences or disciplines: anemografie, astrografie, cronografie, oceanografie.

b. -metru (cf. gr. metron „measure") is a secondary element of composition, which refers to the measurement unit "meter". In the category of maritime terms formed with this suffixoid, we find:

mareometru < Fr. maréomètre, "instrument that determines and records water level variation";

inclinometru $<$ Fr. inclinometer, "instrument used to measure the angles of inclination of a ship";

psicrometru < Fr. psychromètre; "instrument used to measure the level of air humidity"

radiogoniometru < Fr. radiogoniomètre; "instrument used to determine the direction from which radio signals are emitted";

telemetru < Fr. télémètre, cf. gr. tele „far”, metron „measure"; "telemeter, device used to measure distances to remote objects";

accelerometru < Fr. acceleromètre, cf.

Lat. acceleratio „acceleration”, gr. metron "measure", "ectromechanical device that measures acceleration forces; anemometru < Fr. anémomètre; "instrument used for measuring the speed of wind";

axiometru < Fr. axiomètre; "device indicating the position of the rudder to the longitudinal axis of the ship";

barometru < Fr. baromètre, (cf. gr. baros

„weight”, metron „measure”),

"barometer".

We can see from the above examples that there is a synonymy aimed at the affixes -graf and -metru. The following terms designate the same concept, although by way of different suffixes:

barograf - barometru; cronograf cronometru; maregraf - mareometru, anemograf - anemometru ş. a.

c. -fon (< Fr. -phone, cf. gr. phone) is a secondary element of composition meaning "(about) sound", "speech", "speaker", "phonation". (In DN) This suffixoid is often found in nouns denoting devices on ships:

megafon < Fr. mégaphone; "device used

for at long-distance communication";

radiotelefon < Fr. radiotéléphone, "radiotelephone";

izofon (adj.+noun) < izo- + -fon, "line joining points with the same speed of sound in seawater";

nautofon < Fr. nautophone "acoustic signaling device used during fog";

antifon < Fr. antiphone "earplug";

diafon < Engl., Fr. diaphon; "diaphone, type of foghorn producing a low-pitched signal";

hidrofon $<$ din Fr. hydrophone "hydrophone, type of underwater microphone".

d. -nomíe (< Fr. -nomie, It., Lat. -nomia, cf. Gr. nomos "rule, law") is an element of composition meaning "leadership," "management", "governance" (in DN), which is less productive than other suffixoids: astronomie $<\mathrm{Fr}$. astronomie, Lat. astronomia; autonomie < Fr. autonomie, Lat. autonomia, cf. Gr. autos „oneself”, nomos "lege".

The examples cited above help us restate the following conclusions regarding the use of suffixoids in the Romanian maritime terminology: - Etymologically speaking, the suffixoids functioning as root words are, in their majority, of Greek origin;

- In some cases, the Romanian maritime terms are formed with a prefixoid plus a suffixoid, as in the following examples: radiofon, astrograf, cronograf, telemetru, izofon, hidrofon, etc. 
"Mircea cel Batran" Naval Academy Scientific Bulletin, Volume XX - 2017 - Issue 1

The journal is indexed in: PROQUEST / DOAJ / Crossref / EBSCOhost / INDEX COPERNICUS / DRJI / OAJI I JOURNAL INDEX I I2OR / SCIENCE LIBRARY INDEX / Google Scholar / Academic Keys/ ROAD Open Access I

Academic Resources / Scientific Indexing Services / SCIPIO / JIFACTOR

- A clear distinction between the constructions formed in Romanian and the borrowed neologisms can sometimes be very difficult to draw. But, as we have already argued, in order to trace the lexical physiognomy of the Romanian maritime vocabulary, we consider useful to address all terms formed with pseudoprefixes whether loans or recent creation of the Romanian language.

Finally, we note that the derivation using prefixes and prefixoids, suffixes and suffixoids is a process that is used very actively and effectively to create maritime terms in Romanian. The prefixoids and suffixoids are highly representative of the scientific nature of Romanian maritime vocabulary, and together with the neological suffixes and prefixes, the neologisms and the international phrases define it and put it in the category of the modern specialized languages in step with the evolution of science and technology.

\section{Bibliography:}

[1] BUSUIOC, Ileana, CUCU, Mădălina, 2003, Introducere în terminologie, Universitatea din Bucureşti: http://ebooks.unibuc.ro/filologie/terminologie/index.htm

[2] CIOBANU, F., HASAN, F., 1970, în: Formarea cuvintelor în limba română, vol. I Compunerea, Bucureşti: Editura Academiei Române, pp. 243-260.

[3] DIMITRESCU, Florica, 1970, „Quelques aspects de la pseudopréfixation dans la langue roumaine actuelle", în Actele celui de-al XII-lea Congres internaţional de lingvistică şi filologie romanică, I, pp. 925-929.

[4] DIMITRESCU, Florica, 1994, Dinamica lexicului limbii române, Bucureşti: Editura Logos.

[5] GRAUR, Alexandru, 1965, La romanité du roumain, Bucureşti: Editura Academiei.

[6] IORDAN, Iorgu, 1948, Limba română actuală. O gramatică a „greşelilor”, ed. a II-a, Bucureşti.

[7] IORDAN, Iorgu, 1956, Limba română contemporană, Bucureşti: Editura Universităţii Bucureşti.

[8] LÉON, P., Bhatt,P., 2005, Structure du français moderne, 3ème Edition revue, Toronto: Canadian Scholars' Press Inc.

[9] ZUGUN, Petru, 2000, Lexicologia limbii române, Bucureşti: Tehnopress. 